\title{
Effect of Season of the Year on Yields of Several Varieties of Dry Beans Growing in Two Ecological Regions of Puerto Rico ${ }^{1,2}$
}

\author{
José Lozano, Edmundo Rivera, and Fernando Abruña ${ }^{3}$
}

\section{ABSTRACT}

Beans (Phaseolus vulgaris) yielded most at Orocovis, in the humid mountain region of Puerto Rico when they were planted in November and May, and least when planted in March and September. The varieties Black Turtle and Bonita 2, 3 and 8 produced the highest average yields. In Gurabo, in the humid Caguas valley beans yielded highest when they were planted in November, January and March. Yields started to drop off in the May plantings and were very low in the July and September plantings. The varieties Violeta and Naranjito produced the highest average yields.

\section{INTRODUCTION}

Dry beans (Phaseolus vulgaris) are the major source of protein in most countries of Latin America. About 35\% of the world crop of beans is produced in this area; Brazil is the major producer with 2.5 million metric tons harvested annually (5). Most of the beans in the tropics are produced in small plantings along with corn and other food crops.

Nearly all dry beans consumed in Puerto Rico are imported. Consumption is around $7 \mathrm{~kg} /$ capita or a total consumption of 22,000 metric tons yearly, worth $\$ 10$ million.

Most research on dry beans in Puerto Rico and elsewhere in the tropics has been concerned with varieties and planting distances $(1,2,3)$. Guadalupe (4), recently studied the effect of planting dates on yields of beans grown with irrigation in the semiarid region of Puerto Rico. $\mathrm{He}$ confirmed from his work with six varieties of dry beans that beans yield highest when planted in winter and lowest when planted in the fall. There is little information on the effect of planting dates on yields of beans growing in the humid region of Puerto Rico.

Cooler weather from November to March would be expected to result in higher yields during these periods. In Cuba, González (2) obtained higher yields of dry beans from October to January. Pierre (7) found that under normal weather conditions in Jamaica, dry beans produce higher

\footnotetext{
${ }^{1}$ Manuscript submitted to Editorial Board August 24, 1982.

${ }^{2}$ This paper covers work carried out cooperatively between ARS-USDA and the Agricultural Experiment Station, College of Agricultural Sciences, Mayagüez Campus, University of Puerto Rico, Rio Piedras, PR.

${ }^{3}$ Research Assistant, Agricultural Experiment Station, College of Agricultural Sciences, Mayagüez Campus, University of Puerto Rico; Agronomist, and Soil Scientist, ARS-USDA, respectively.
} 
yields during the cooler days of winter. Smith and Pryor (9) have shown that high temperatures reduce flowering and pod setting, and Sehni and Morgan (8) found that increasing the day length to 11 hours inhibited flowering of dry bean varieties from Colombia.

The present research was conducted to determine the effect of planting: dates on yields of dry beans grown at Orocovis and Gurabo.

\section{MATERIALS AND METHODS}

One experiment was carried out on Humatas clay (Typic Tropohumults) on a $15 \%$ slope near Orocovis. The soil, with a cation exchange capacity of $11 \mathrm{me} / 100 \mathrm{~g}$ of soil, was limed to pH 5.5. Twenty-six bean

TABLE 1.-Monthly rainfall and average daily temperature at Orocovis and Gurabo during the year of exprimentation

\begin{tabular}{lccccc}
\hline \multirow{2}{*}{ Month } & \multicolumn{3}{c}{ Orocovis } & \multicolumn{3}{c}{ Gurabo } \\
\cline { 2 - 3 } \cline { 5 - 6 } $\begin{array}{c}\text { Rainfall } \\
(\mathrm{mm})\end{array}$ & 86 & $\begin{array}{c}\text { Mean } \\
\text { Temp. C }\end{array}$ & & $\begin{array}{c}\text { Rainfall } \\
(\mathrm{mm})\end{array}$ & $\begin{array}{c}\text { Mean } \\
\text { Temp. C. }\end{array}$ \\
\hline January & 38 & 21 & & 84 & 22 \\
February & 76 & 21 & & 18 & 23 \\
March & 81 & 21 & & 35 & 23 \\
April & 532 & 23 & & 204 & 24 \\
May & 178 & 24 & & 10 & 25 \\
June & 233 & 25 & & 116 & 26 \\
July & 166 & 26 & 302 & 26 \\
August & 279 & 26 & 300 & 26 \\
September & 468 & 26 & & 144 & 26 \\
October & 326 & 23 & 555 & 26 \\
November & 330 & 22 & 97 & 25 \\
December & 168 & 21 & 49 & 22 \\
January & & & & 22 \\
\hline
\end{tabular}

varieties were planted in a randomized block design in plots $4 \times 4 \mathrm{~m}$. Planting distance was $45 \mathrm{~cm}$ between rows and $10 \mathrm{~cm}$ between plants. Fertilizer (10-10-10) was applied at the rate of $1,200 \mathrm{~kg} / \mathrm{ha}$ at planting. The plots were sprayed once every 15 days, to control insects and diseases. All varieties were planted at varying intervals throughout a 1-year period starting March 1977.

A second experiment was planted near Gurabo on a 3\% slope of Mabi clay (Vertic Eutropepts), with a pH of 6.8 and an effective cation exchange capacity of $28 \mathrm{me} / 100 \mathrm{~g}$ of soil (6).

Six commercial varieties of dry beans were planted in a randomized block design in plots $4 \times 4 \mathrm{~m}$. Bimonthly plantings were made during a full year, starting January 1977. Planting distances, fertilization, and 
TABLE 2.-Effect of season of the year on yield of 26 varieties of beans grown at Orocovis, P.R.

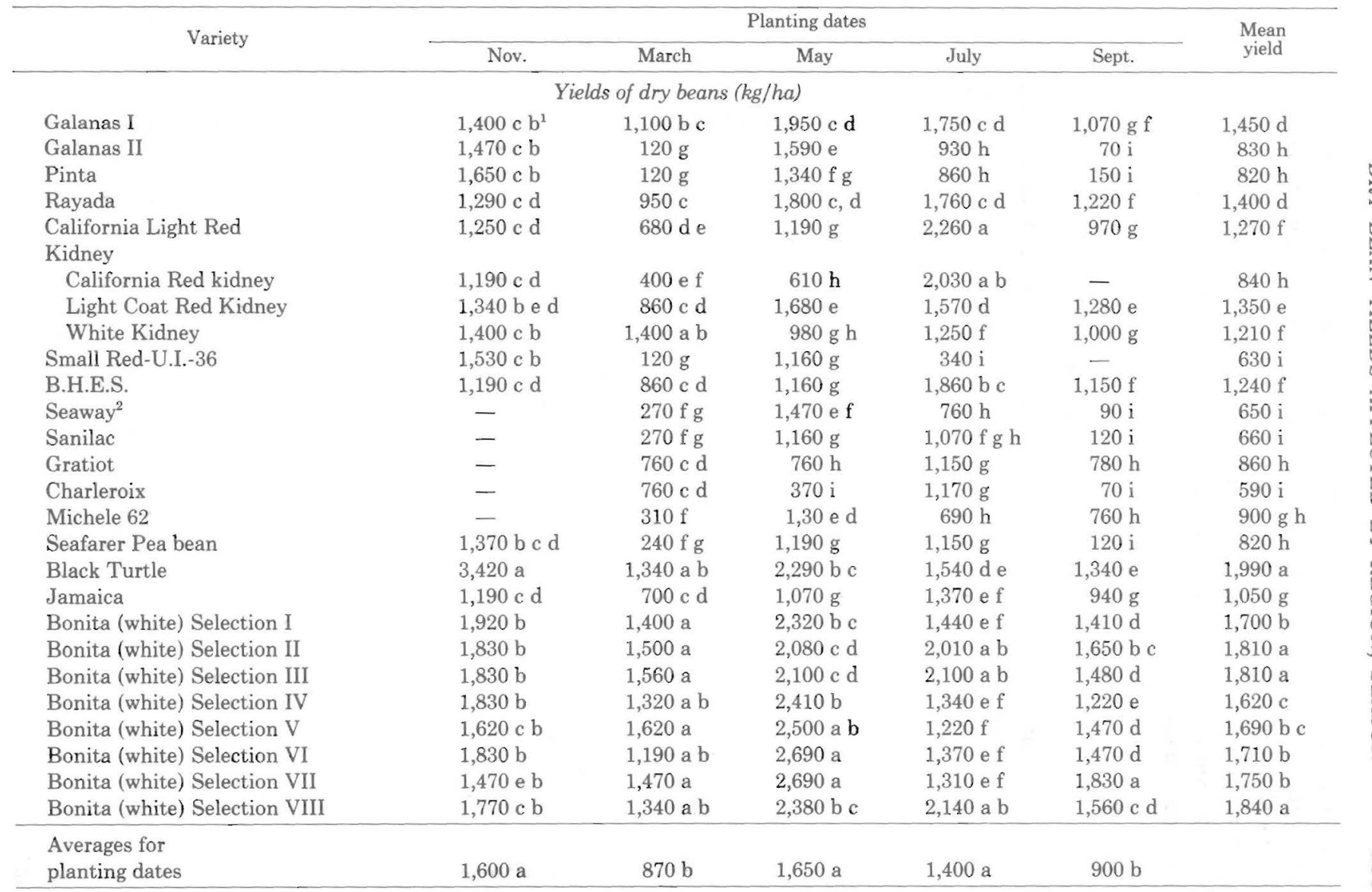

${ }^{1}$ Values followed by one or more letters in common do not differ statistically at the 0.05 level. (Duncan's multiple range test).

${ }^{2}$ Varieties Seaway, Sanilac, Gratiot, Charleroix and Michele 62 were not planted in November, because no seed was available at that time. 
pest control were the same as those described above for the Orocovis experiment, except that sprinkler irrigation was applied whenever rainfall was less than $20 \mathrm{~mm}$ per week.

In both experiments all plots were harvested when moisture content of the beans was about $25 \%$, and yields were determined on a $14 \%$ moisture basis.

\section{RESULTS AND DISCUSSION}

\section{OROCOVIS EXPERIMENT}

Annual rainfall was $2,790 \mathrm{~mm}$, unevenly distributed throughout the year, and mean daily temperatures varied from 21 to $26^{\circ} \mathrm{C}$ (table 1 ),

Season of the year strongly affected bean yields (table 2 and figure 1 ).

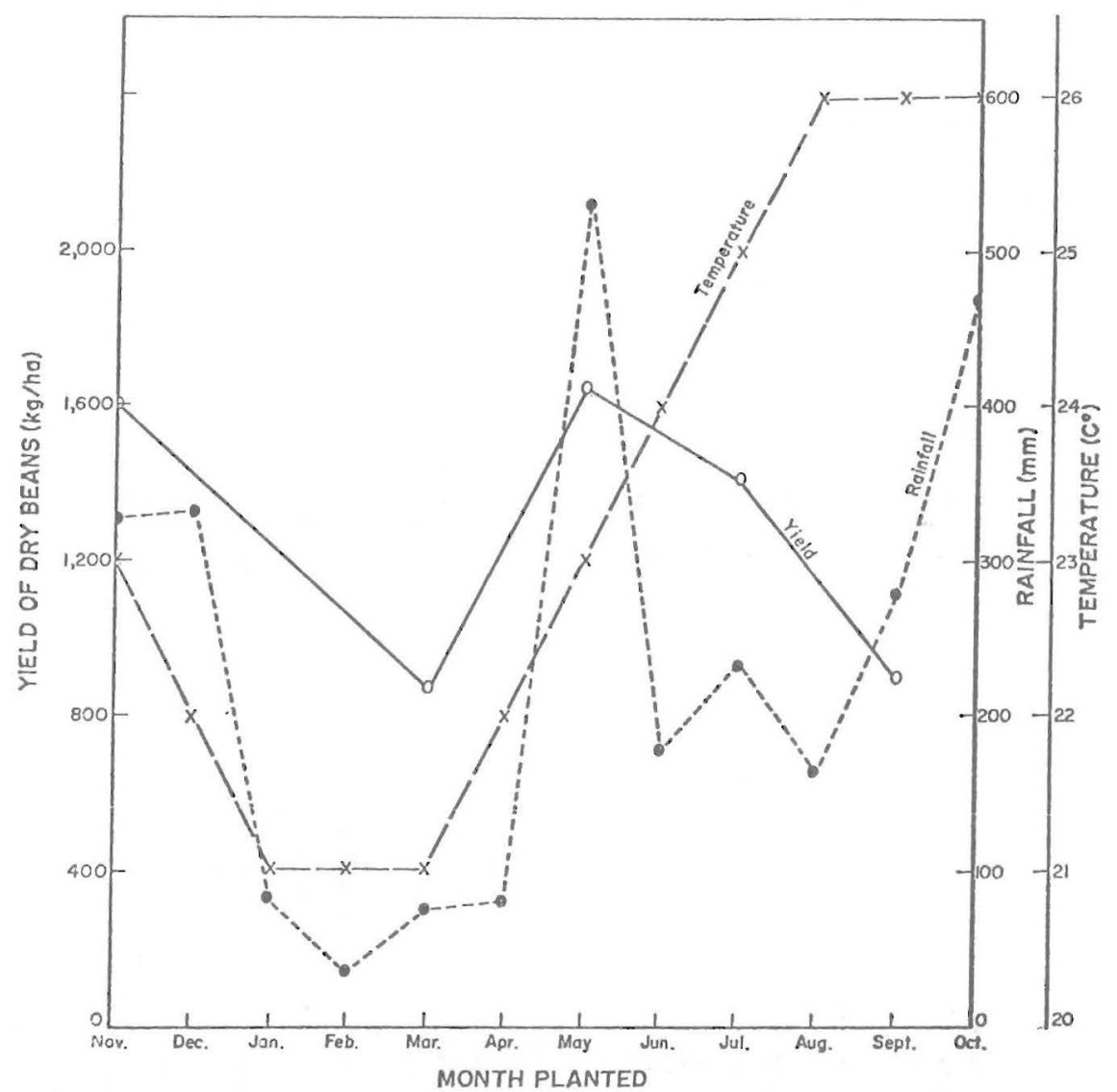

FIG. 1.-Effect of month of planting on average yields produced by twenty-six varieties of beans at Orocovis. 
The November, May and July plantings produced higher yields than the March or September plantings. The low yields produced by the March planting were a result of the unusually high rainfall at harvest time in May $(532 \mathrm{~mm})$ with over half the beans rotting in the field. On the other hand, the May planting produced high yields because it was harvested in early August, which was unusually dry, and the fairly cool weather in the spring in the uplands permits good yields if rainfall is not excessive. Yields were low in the September plantings because of high temperatures and rainfall (fig. 1).

Black Turtle variety produced the highest yields in the November planting, followed by most of the Bonita selections (table 2). Most Bonita selections and the Black Turtle and White Kidney varieties produced

TABLE 3.-Effect of season of the year on yield of six bean varieties grown at Gurabo, P.R.

\begin{tabular}{|c|c|c|c|c|c|c|c|}
\hline \multirow[b]{2}{*}{ Variety } & \multicolumn{6}{|c|}{ Planting Dates } & \multirow[b]{2}{*}{ Mean yield } \\
\hline & Jan. $17 / 77$ & $\begin{array}{l}\text { March } \\
24 / 77\end{array}$ & $\begin{array}{l}\text { May } \\
18 / 77\end{array}$ & $\begin{array}{c}\text { July } \\
21 / 77\end{array}$ & $\begin{array}{l}\text { Sept. } \\
21 / 77\end{array}$ & Nov. $20 / 77$ & \\
\hline \multicolumn{8}{|c|}{$\mathrm{kg} / \mathrm{ha}$} \\
\hline Oro Rico & $2,040 \mathrm{a}^{1}$ & $2,320 \mathrm{a}$ & $1,320 \mathrm{a}$ & $190 \mathrm{~d}$ & $230 \mathrm{~b} \mathrm{c}$ & $2,260 \mathrm{a}$ & $1,390 \mathrm{bc}$ \\
\hline Bonita & $1,900 \mathrm{a} \mathrm{b}$ & $2,080 \mathrm{a} b$ & $1,500 \mathrm{a}$ & $570 \mathrm{~b} \mathrm{c}$ & $120 \mathrm{c}$ & $2,050 \mathrm{ab}$ & $1,370 \mathrm{~b} \mathrm{c}$ \\
\hline Naranjito & $2,230 \mathrm{a}$ & $1,720 \mathrm{c}$ & $1,730 \mathrm{a}$ & 860 a & $410 \mathrm{a}$ & $2,060 \mathrm{a} b$ & $1,500 \mathrm{a} \mathrm{b}$ \\
\hline Congo Rico & $1,490 \mathrm{~b}$ & $1,990 \mathrm{~b}$ & $1,520 \mathrm{a}$ & $420 \mathrm{c} \mathrm{d}$ & $360 \mathrm{ab}$ & $1,810 \mathrm{bc}$ & $1,270 \mathrm{c}$ \\
\hline Violeta & $2,370 \mathrm{a}$ & $2,150 \mathrm{a} b$ & $1,820 \mathrm{a}$ & $510 \mathrm{~b} \mathrm{c}$ & $490 \mathrm{a}$ & $1,900 \mathrm{~b} \mathrm{c}$ & $1,540 \mathrm{a}$ \\
\hline Palmarejo & $2,220 \mathrm{a}$ & $1,370 \mathrm{~d}$ & $1,360 \mathrm{a}$ & $340 \mathrm{c} \mathrm{d}$ & $350 \mathrm{a} b$ & $1,700 \mathrm{c}$ & $1,220 \mathrm{c}$ \\
\hline $\begin{array}{l}\text { Average for } \\
\text { planting } \\
\text { date }\end{array}$ & $2,040 \mathrm{a}$ & $1,940 \mathrm{a}$ & $1,540 \mathrm{~b}$ & $480 \mathrm{c}$ & $330 \mathrm{c}$ & $1,964 \mathrm{a}$ & \\
\hline
\end{tabular}

${ }^{1}$ Values followed by one or more letters in common do not differ statistically at the 0.05 level. (Duncan's multiple range test).

the highest yields in the March planting. Bonita selections 6 and 7 produced the highest yields in the May planting. Bonita selections 2, 3, and 8 and the California Light and Red Kidney varieties produced the highest yields in the July planting. Bonita selection 7 produced the highest yields in the September planting.

When yields of each variety produced at all seasons were averaged and were compared, Black Turtle and Bonita selections 2, 3, and 8 outyielded the other varieties.

\section{GURABO EXPERIMENT}

Annual rainfall was $1,950 \mathrm{~mm}$, with wide seasonal variations. Mean daily temperature ranged from 23 to $26^{\circ} \mathrm{C}$ (table 1 ).

Season of the year had a marked effect on yields of dry beans. Similar high yields were produced in the November, January and March plantings 
(table 3 and fig. 2). Yields started to drop off with the May planting, and the July and September plantings resulted in very low yields. Figure 2 shows how high temperature and rainfall had a depressing effect on yields.

All varieties produced similar high yields in the January planting with Oro Rico, Naranjito, Violeta and Palmarejo the highest yielders. In the

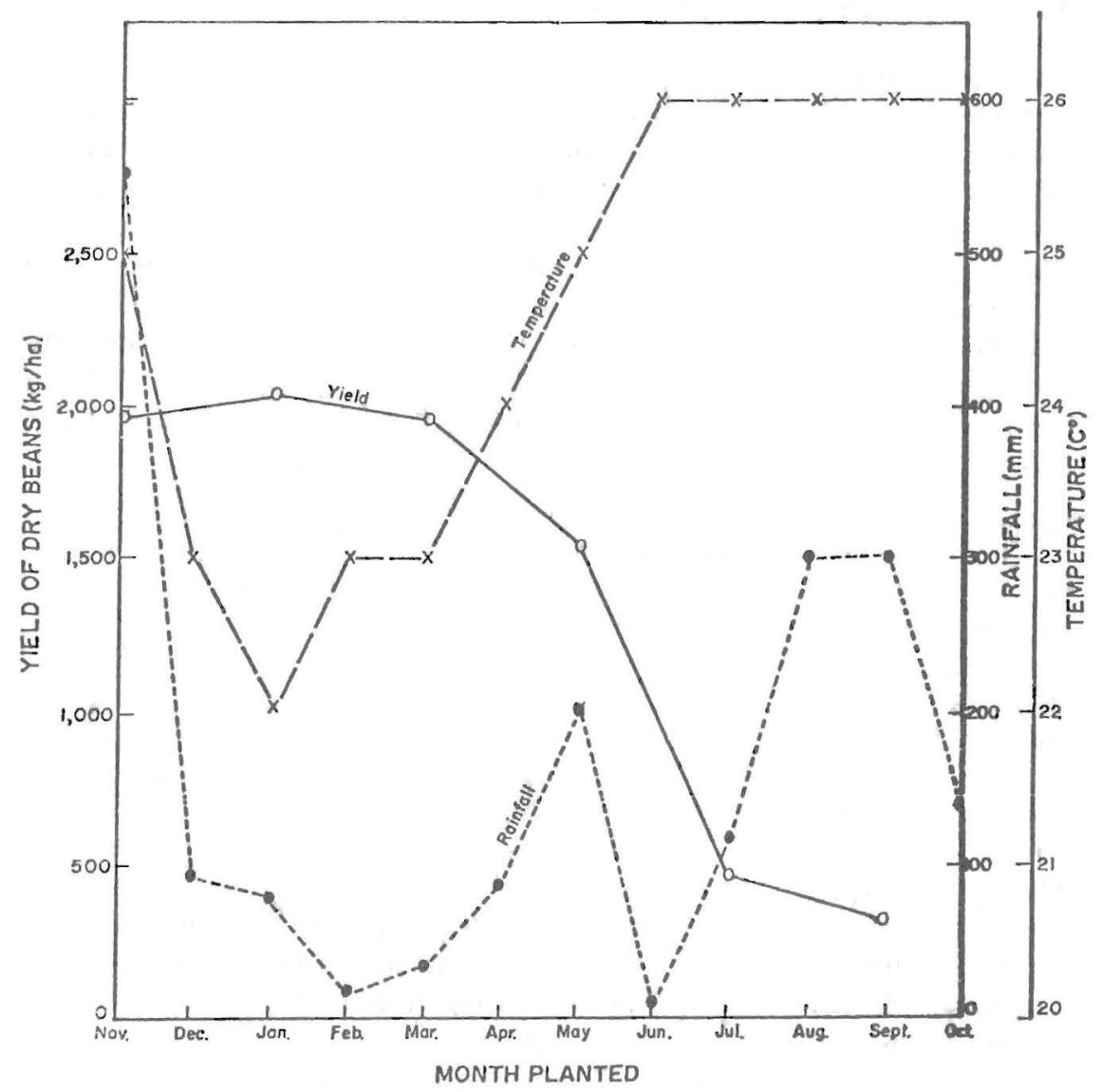

FIG. 2.-Effect of month of planting on average yields produced by six varieties of beans at Gurabo.

March planting, Oro Rico, Bonita and Violeta produced the highest yields. There were no differences in yields among varieties when planted in May. In the July planting, all varieties produced very low yields. Naranjito, although it produced better than the other varieties, yielded less than $900 \mathrm{~kg} / \mathrm{ha}$. The high moisture and temperatures aided the spread of fungus diseases in spite of frequent spraying. September plant- 
ings yielded very low. Violeta variety, the highest yielder, produced only $490 \mathrm{~kg} / \mathrm{ha}$. High yields were again produced in the November planting by Oro Rico, Bonita, and Naranjito varieties.

When the yields of all the plantings of each variety were combined, and compared, Violeta and Naranjito varieties produced the highest mean yields, about $1,500 \mathrm{~kg} / \mathrm{ha}$ (table 3 ).

\section{RESUMEN}

Se determinó el efecto de la época de siembra en la producción de 26 variedades de habichuelas en Orocovis y de 6 variedades en Gurabo.

La época del año tuvo un señalado efecto en la producciôn. En Orocovis, las siembras de noviembre y mayo arrojaron las producciones más altas y las de marzo y septiembre las más bajas, debido en gran medida a las fuertes lluvias durante la época de cosecha. Las variedades Black Turtle y Bonita 2, 3 y 8 produjeron los rendimientos medios más altos.

En Gurabo las producciones fueron similarmente altas en las siembras de noviembre, enero y marzo; se redujeron algo en la de mayo y bajaron mucho en las de julio y septiembre, debido mayormente a temperaturas más altas y la mucha lluvia durante la cosecha. Las variedades Violeta y Naranjito fueron las de producción media más alta.

\section{LITERATURE CITED}

1. Badillo-Feliciano, J., Lugo-López, M. A. and Scott, T. W., 1978. Effect of planting distance on yield and agronomic characteristics of red kidney and native white beans in an Oxisol, J. Agric. Univ. P.R. 62 (2): 145-8.

2. González, A. P., 1975. Investigaciones sobre el comportamiento de algunas variedades de frijol al patógeno causante de la roya. Inst. Invest. Trop. Acad. Cienc. Cuba, p. $14-23$.

3. González-Ríos, P. and Riollano, A., 1951. El mejoramiento de la habichuela blanca del pais (Phaseolus vulgaris) por medio de la selección. Esta. Exp. Agric. Univ. P.R. Bol. 94.

4. Guadalupe, R., 1977. Influencia de la época de siembra sobre el comportamiento de la habichuela seca (Phaseolus vulgaris), Tesis Univ. P.R.

5. Gutiérrez, P. U., Infante, M. and Pirchinat, A., 1975. Situación del cultivo del frijol en América Latina. Cent. Int. Agric. Trop. CATIE. Serie ES-19.

6. Lugo-López, M. A. and Rivera, Luis H., 1977. Updated taxonomic classification of the soils of Puerto Rico. Univ. P.R. Agric. Exp. Stn. Bull. 258.

7. Pierre, R. E., 1974. Yield potential and disease resistance of dry beans (Phaseolus vulgaris) varieties in Jamaica. In Proc. Caribbean Food Crops Soc. 12th Annu. Meet. Jamaica, pp. 165-69.

8. Sehni, M. S. and Morgan, D. G., 1976. A comparative study of the effect of photoperiod on flower bud development and stem elongation in three varieties of Phaseolus vulgaris. Ann. Bot. 40: 17-22.

9. Smith, F. L. and Pryor, R. H., 1962. Effects of maximum temperature and age on flowering and seed production in three bean varieties, Hilgardia 33 (12): 669-88. 